\title{
ПОДАТКОВА СИСТЕМА УКРАЇНИ: СУЧАСНИЙ СТАН ТА НАПРЯМКИ ВДОСКОНАЛЕННЯ
}

Слаблюк Н. С.

у науковій статmі досліджено та проаналізовано сучасний стан податкової системи України, визначено основні недоліки та проблеми функціонування механізму поповнення державного бюджету податками. Визначено напрямки вдосконалення сучасної податкової системи України, акцентовано увагу на напрямку євроінтеграції України, проаналізовані основні недоліки податкової системи України в порівнянні з нормами Європейського Союзу, виділено способи їх усунення. Зроблені висновки щодо вдосконалення сучасної податкової системи України.

Ключові слова: податкова система України, євроінтеграція, податкове законодавство, контролюючі органи, податкова реформа.

В научной статье исследовано и проанализировано современное состояние налоговой системы Украины, определены основные недостатки и проблемы функционирования механизма пополнения государственного бюджета налогами. Определены направления совершенствования современной налоговой системы Украины, акцентировано внимание на направлении евроинтеграции Украины, проанализированы основные недостатки налоговой системы Украины по сравнению с нормами Европейского Союза, выделены способы их устранения. Сделаны выводы о совершенствовании современной налоговой системы Украины.

Ключевые слова: налоговая система Украины, евроинтеграция, налоговое законодательство, контролирующие органы, налоговая реформа.

The aim of this article analyzes the current state of the tax system of Ukraine, identifies the main shortcomings and problems of functioning of the mechanism of replenishment of the state budget with taxes. The directions of improvement of the modern tax system of Ukraine, the attention are focused on the direction to European integration of Ukraine, analyzed the main shortcomings of the tax system of Ukraine in comparison with the norms of the European Union, identified ways to eliminate them. Conclusions are made on the improvement of the modern tax system of Ukraine.

The purpose of this article is to present the modern tax system of Ukraine and to indicate the mechanisms for its improvement in connection with the intentions of joining the European Union. The essence and legal nature of the modern tax system of Ukraine are investigated. The analysis of weaknesses of the tax system of Ukraine is carried out. On the basis of foreign experience, conclusions are made on the need to improve the tax system of Ukraine.

The author notes that the direction of European integration of Ukraine is a positive phenomenon, as it will prompt the legislator to implement changes and reforms in tax law.

Unfortunately, the constant changes taking place in the tax system of Ukraine, although aimed at improving it, do not always work for the benefit of taxpayers. All this is due to sufficient gaps in legislation and the ineffectiveness of innovations. Therefore, in today's conditions, when the tax system of Ukraine is in a constant transformation, such innovations are needed that would secure a stable and proportional flow of taxes to the budget, while contributing to the development of economic activity in Ukraine.

Key words: tax system of Ukraine, eurointegration, tax legislation, control bodies, tax reform.
Постановка проблеми та її актуальність. Податкова система України відіграє важливу роль у формуванні державних доходів, протягом тривалого часу спостерігаються постійні зміни в податковому законодавстві, спрямовані на їі вдосконалення та розвиток. Проте на сьогодні $\epsilon$ гостра проблема в стабільності податкової системи України. Часті зміни в законодавстві спонукають платників податку на постійний моніторинг та аналіз чинного податкового законодавства. Незважаючи на реформи щодо податкового законодавства, сьогодні існують проблеми щодо ефективності функціонування податкової системи України, що зумовлено прогалинами в законодавстві та неефективністю нововведень. До того ж, зважаючи на прагнення України до вступу в Європейський Союз, виникає необхідність привести податкову систему України в узгодження з нормами європейського законодавства.

Аналіз останніх досліджень і публікацій. Питання щодо стану сучасної податкової системи та напрямків iï вдосконалення розглядалось такими українськими вченими: Ю.М. Мельничук, Л.В. Трофімовою, Т.В. Єфименко, Л.Н. Бурковою, Г.А. Білецькою та іншими. Проте проблема дослідження напрямків удосконалення податкової системи з урахуванням сучасних умов ринкової економіки у зв'язку з щорічними змінами законодавства України та сучасною євроінтеграцією України $\epsilon$ надзвичайно актуальною.

Метою цієї статті $€$ дослідження сучасного стану податкової системи України, виявлення основних їі недоліків та розгляд перспектив побудування податкової системи України відповідно до принципів побудови податкової системи країн Європейського Союзу.

Виклад основного матеріалу. Податкова система України представляє собою сукупність загальнодержавних та місцевих податків і зборів, що справляються в установленому законодавством порядку до бюджетів різних рівнів. Варто зазначити, що податкова система $\epsilon$ однією з найскладніших у правовій системі України, при цьому спостерігається тенденція щодо ії нестабільності протягом багатьох років, це зумовлено постійними змінами в законодавстві. Податкова система України почала своє формування ще із часів набуття нашою державою незалежності, але й до сьогодні цей процес залишається незавершеним. Постійні зміни, що відбуваються в податковій системі України, хоча і націлені на іiї вдосконалення, насправді не завжди працюють на благо платників податків. Приймаючи до уваги те, що сьогодні роль податків має великий вплив на суб'єктів господарювання та чине вплив на соціально-економічний розвиток суспільства, держава повинна сприяти постійному вдосконаленню податкової системи. Проблема побудови ефективної податкової системи - одна з найбільш актуальних в Україні. Ї̈̈ вирішення повинно 
здійснюватися шляхом вивчення й аналізу як існуючої в Україні законодавчої бази, так і накопиченого у світі досвіду у сфері оподаткування [4, с. 76].

Для з'ясування внутрішнього змісту податків, їх ролі у формуванні податкової системи України необхідно виділити системний підхід до визначення функцій податків:

1. Фіскальна функція. Полягає в тому, що держава повинна отримувати не просто достатню кількість надходжень до державного бюджету, а вони мають бути постійними і стабільними. Постійність означає, що податки мають надходити до бюджету не у вигляді разових платежів із невизначеними термінами, а рівномірно протягом бюджетного року в чітко встановлені строки. Стабільність надходжень визначається достатнім рівнем гарантій того, що доходи, передбачені Законом України «Про Державний бюджет України», будуть отримані в повному обсязі. Крім того, одним із принципів податкового законодавства України $\epsilon$ фіскальна достатність, а саме встановлення податків та зборів з урахуванням необхідності досягнення збалансованості витрат бюджету з його надходженнями [1].

2. Регулююча функція. Полягає в перерозподілі вартості валового національного продукту між державою та платниками податків. Податки при цьому повинні стати особливими механізмами, які зможуть забезпечити баланс особистих і загальнодержавних інтересів. Також важливо зазначити, що ця функція являє собою сукупність можливостей впливу податкової системи на перебіг соціально-економічних процесів у державі, які можуть бути реалізовані за допомогою податкових важелів.

Для реалізації обох функцій податкова система повинна включати досить різноманітні види податків, які мають різну цілеспрямованість. Порядок стягнення податків визначається Податковим кодексом України, норми якого зазнають постійних змін, що дуже негативно вливає на стабільність податкової системи.

Сьогодні Україна йде шляхом євроінтеграції, тож корегування існуючого інституційного механізму оподаткування має бути здійснено з урахуванням вимог Європейського Союзу. У Європейському законодавстві існують Директиви щодо побудови системи оподаткування. Наразі Україна не $\epsilon$ країною - членом Європейського Союзу, та норми Директив не $\epsilon$ загальнообов'язковими для виконання, проте слід зазначити, що наразі вести мову про можливе імплементування вищевказаних норм Україною буде досить складно [3, с. 110]. Необхідно констатувати, що рівень економічного, соціального і політичного розвитку України не відповідає європейському, а відповідно, норми і інститути податкового права, адаптовані для країн Європи, не можуть бути застосовані в Україні.

На відміну від країн Європейського Союзу, податкова система України не $\epsilon$ інструментом підвищення конкурентоспроможності держави, не сприяє зростанню економічної активності суб'єктів господарювання. Існуюча система формування державних доходів відображає недосконалість перехідної економіки та має переважно фіскальний характер, тобто спрямована, в першу чергу, на поповнення державного бюджету [5, с. 15-18]. Ринкове реформування економіки супроводжувалося неодноразовими спробами вдосконалити податкову систему шляхом прийняття окремих законодавчих актів, що були недостатньо адекватними стану економіки, характерними рисами якої є структурні диспропорції, наявність значних обсягів тіньових оборотів, платіжна криза.

Слід звернути увагу на тлумачення норм податкового законодавства. Неоднозначність тлумачення податкового законодавства негативно позначається на діяльності суб'єктів господарювання, знижує привабливість національної економіки для іноземних інвесторів. Із 1 січня 2011 року на законодавчому рівні закріплено право платників податків на отримання від контролюючих органів індивідуальної податкової консультації і визначення її правових наслідків для платників: фінансової, адміністративної, кримінальної відповідальності та нарахування пені. Таким чином, індивідуальна податкова консультація $\epsilon$ правом платника, яким він за необхідності може скористатись [2, с. 23-28]. Проте на практиці платнику податків досить важко отримати обґрунтовану відповідь від контролюючого органу та скористатись нею, дуже часті випадки, коли контролюючий орган або надає відповідь із великою затримкою в часі, або надає невмотивовану і необґрунтовану відповідь, що $є$ негативним явищем для платника податку.

Важливо відзначити, що діяльність Міністерств та Центральних органів виконавчої влади не $\epsilon$ достатньо узгодженою, відсутній цілісний інформаційний простір між організаціями, що призводить до дублювання функцій. Так, наприклад, органом виконавчої влади, який забезпечує формування та реалізує державну політику у сфері дотримання суб'єктом господарювання законодавства про працю, зокрема трудових відносин, $\epsilon$ Державна служба України з питань праці. Саме цей орган державної влади під час інспекційних відвідувань із питань виявлення неоформлених трудових відносин за наявності відповідних підстав самостійно та в будьякий час доби з урахуванням вимог законодавства про охорону праці може проходити до будь-яких виробничих, службових, адміністративних приміщень об'єкта відвідування, в яких використовується наймана праця. У цей же час пп. 80.2.7 Податкового кодексу України передбачено, що фактична перевірка платника податку може проводитись, зокрема, з такої підстави, як отримання в установленому законодавством порядку інформації про використання праці найманих осіб без належного оформлення трудових відносин. Отже, за один контролюючий захід відповідають два органи державної влади. Доцільно було б чітко розподілити обов'язки кожного окремого контролюючого органу та узгодити напрямки його діяльності.

Для усунення недоліків, що існують у податковій системі України, насамперед необхідно привести законодавчу базу у відповідність до європейських Директив та принципів. Перш за все це, стосується конституційної реформи, адже чинна редакція Конституції України не дає чітко визначеного розподілу повноважень між різними гілками влади, що може заважати ефективному функціонуванню владних інституцій [4, с. 78].

Для реалізації сучасних цілей України щодо вдосконалення податкової системи слід провести податкову реформу, яка б включала в себе:

1) засоби автоматизації процесів оподаткування із залученням сучасних технологій;

2) поступову адаптацію сучасного законодавства України до законодавства Європейського Союзу; 


\section{Правове забезпечення адміністративної реформи}

3) скорочення витрат платників на сплату податків i їх адміністрування;

4) підвищення заінтересованості суб'єктів господарювання у веденні бізнесу на території України (надання пільгового періоду суб'єктам господарювання на початку їх діяльності);

5) залучення іноземних інвестицій шляхом надання пільг на окремі види діяльності.

Незважаючи на певні кроки нашої держави в напрямку гармонізації податкового законодавства України до вимог Європейського Союзу, податкова система України, на відміну від країн Європейського Союзу, не сприяє побудові соціально орієнтованої конкурентоспроможної ринкової економіки [6, с. 365]. Стан функціонування податкової системи сьогодні не можна порівняти 3 жодною європейською державою ні за економічним розвитком, ні за податковою культурою, ні за рівнем обізнаності платників податку.

Висновки. Підбиваючи підсумки, необхідно констатувати, що найгострішими проблемами сучасної податкової системи України є: складність та неузгодженість податкового законодавства, нестабільність норм щодо оподаткування, надмірне податкове навантаження з боку контролюючих органів та постійні конфлікти між контролюючими органами та платниками податків, дублювання повноважень контролюючих органів, відсутність реальних пільг для стимуляції ведення господарської діяльності, відсутність механізму залучення іноземних інвестицій тощо. Бажання України приєднатись та стати повноправним членом Європейського Союзу зумовлює необхідність провести роботу щодо гармонізації вітчизняної податкової системи до норм Європейського Союзу. Для забезпечення нової подат- кової системи необхідне поступове зниження вагомості й досягнення оптимального значення загального податкового навантаження на всі види діяльності. Також необхідне зменшення кількості контролюючих органів з одночасним створенням єдиних правил контролю за податками та чітке розмежування функцій контролюючих органів, також необхідне поетапне зниження податкового навантаження на платників податку задля стимулювання національних i iноземних інвестицій у державну економіку.

\section{Література}

1. Податковий кодекс України від 02 грудня 2010. Відомості Верховної Ради. 2011. № 13-14, № 15-16, № 17. СТ. 112.

2. Єфименко Т.В., Про основні напрями реформування податкової системи України: проблеми теорії і практики. Збірник наукових праць НДФІ. 2003. С. 23-28.

3. Іголкін І.В. Податкова реформа як об'єктивна необхідність зміцнення дохідної частини державного бюджету. Фінанси України. 2005. С. 110.

4. Мельничук Ю.М. Реформування податкової системи: Перспективні напрямки наукової думки: Юриспруденція. Тернопіль. 2018. С. 75-79.

5. Попова В.В. Удосконалення структурно-організаційної моделі податкової політики в умовах євроінтеграції. Економіка. Фінанси. Право. 2016. Вип. 11. С. 15-18.

6. Трофімова Л.В. Податкова політика і податкова система. Фінансове право. 2015. С. 364-370.

Слаблюк Н. С., магістр права, юрисконсульт юридичного відділу ТОВ «Компанія Скай Сервіс» 